\title{
A qualitative study of the relationship of personality type with career management and career choice preference in a group of bioscience postgraduate students and postdoctoral researchers
}

\author{
Sarah Blackford, \\ Society for Experimental Biology, \\ Bailrigg House, \\ Lancaster University, \\ Lancaster LA1 4YE \\ UK \\ s.blackford@lancaster.ac.uk \\ 07771765335
}

\begin{abstract}
This study reports on the career management and career choice preferences of a sample of bioscience postgraduate students and postdoctoral researchers according to their personality type as determined using the Myers Briggs Type Indicator (MBTI). Correlations can be found but other decision-making processes come into play and are more influential regarding career choices.
\end{abstract}

\section{Keywords}

Bioscience; postgraduate students; postdoctoral researchers; career management; career preference; Myers Briggs Type Indicator (MBTI); personality type

\begin{abstract}
Aim
The aim of this study was to investigate whether personality (measured here as Psychological Type) has an influence on career management style and career preference. The study was conducted on a group of bioscience postgraduate students and postdoctoral researchers who had previously attended a one-day career development workshop. The qualitative survey analysis aimed to determine whether there is a relationship between a person's preference for particular aspects of their career management such as skills development and everyday tasks (e.g. devising experiments, attending conferences, writing papers, analysing data) and their career preferences (e.g. on their preference for particular types of work).
\end{abstract}

\section{Introduction}

The data presented in this paper were collected following as series of career development workshops which comprised the four main elements of the career learning DOTS Model (Law and Watts, 1977; Law, 1999): decision-making, opportunity awareness, transition (e.g. CVs and interview technique) and selfawareness (such as personality, skills and values). In a previous paper (Blackford, $2010)$, data are presented which show that this cohort group $(\mathrm{N}=178)$ of bioscience postgraduate students and postdoctoral researchers had a higher than average (X3) proportion of 'Rational' and 'Logical' types (as determined using the MBTI analysis) compared with a population of undergraduate students. It was postulated in the paper that these personality types may be more likely to be drawn towards a 
research/academic career than students with other personality types. Previous studies have shown that significant correlations can be drawn between personality type and career preference: Johnson and Singh (1998) report on the personality of civil engineers showing a ratio of the preference scales to be similar to that of bioscientists; a study carried out by Stilwell et al (2000) of medical students, as reported by Barshes et al (2004), showed that male, extraverted thinking types are more likely to choose a career in surgical specialities; and a study by Capretz (2008) reports on the psychological types of Brazilian software engineering students as compared with the general Brazilian population and finds that the engineers are significantly likely to be more introverted.

In this study the career preference and career management styles of a small group of the workshop participants were examined using a qualitative survey method. It was considered that the results would be interesting to researcher development managers, skills coordinators and careers advisers who deal with postgraduate students and postdoctoral staff since it is well recognised that the academic career path is limited and highly competitive, thus requiring the majority of postgraduate students and postdoctoral researchers to seek alternative careers (Bradley, 2009), whilst the minority aiming for academia need to be highly focussed and equipped to meet the required criteria. Leaving academic research is generally viewed negatively by this cohort group and their supervisors (anecdotal), however, it is a matter for debate whether some people are better suited to these 'alternative careers'. The survey was aimed at partially examining this hypothesis with respect to personality type by qualitatively surveying the career management and career choice preferences of a small sample of the group.

\section{Definition of key terms and vocabulary}

\section{Bioscience postgraduate and postdoctoral researchers (PGs and PDs)}

- 'Bioscience' relates to any biological science discipline and, within the cohort group, ranged from ecology, agricultural and environmental science through to medicine, veterinary and forensic science.

- The vast majority of postgraduates were PhD students with just a handful of masters students included in the cohort. They were at various stages of progress ranging from $1^{\text {st }}$ year through to the writing up stage ( $4^{\text {th }}$ year).

- Postdoctoral researchers and some PhD students varied in age from early 20 's through to early 50's. Some PDs were in their first postdoc position, others were seasoned PDs with additional senior responsibilities such as grant-writing, student supervision and lecturing. Some, however, had not gained any additional managerial responsibilities above that which they had during their first postdoctoral position.

The range in ages of the PDs and PGs impacted on their personal circumstances and affected aspects of their career decision-making process, e.g. their mobility, family commitments, entrenchment in a familiar environment and career.

\section{Career management}


The definition of career management is defined in terms of the following factors according to 'National Career Development Week':

- Understanding one's own strengths and weaknesses, needs and wants

- Ability to identify relevant opportunities

- Accessing career information

- Ability to plan and take career-related decisions

- Ability to present oneself effectively in order to gain access to courses or jobs

- Ability to network and build relationships

\section{Career preference}

This refers to preferred career choice, with regard to a person's next career transition depending on their decision-making process which can factor in aspects such as personality, preferred working environment, values, knowledge, abilities, personal situation, etc.

\section{Myers-Briggs Type Indicator}

The Myers-Briggs Type Indicator (MBTI) is a personality instrument based on the work of Carl Jung (Jung, 1923). The six components of his work are based on how we take in information (sensing (S)/intuition(N)), how we make decisions (thinking $(T) /$ feeling $(F)$ ) and whether we derive our energy from the external or internal world (extraversion (E)/introversion (I)). Mother and daughter team, Katherine Briggs and Isabel Briggs Myers, introduced two more components to this theory: how we organise our lives (judging $(\mathrm{J}) /$ perceiving $(\mathrm{P})$ ) and designed and developed the MBTI personality instrument. The history of the creation of MBTI is reported by McCaulley and Martin (1995) where they describe some of the many applications of the instrument and allude to the preferred careers of certain personality types. The combination of all the components of the MBTI make up 16 possible personality types made up of E/I, S/N, T/F and J/P. Whilst acknowledging that the MBTI is not about 'pigeon-holing' people and forcing them into one 'box', rather to raise awareness of one's own strengths and areas for development, descriptions of each of the four preferences of the MBTI is set out in McCaulley and Martin (1995) as follows:

\section{Extravsion/Introversion}

When extraverting we turn our attention to the outside world, people, objects and changing scene around us. People who prefer extraversion tend to give weight to these interactions and want to be part of the action. They tend to gravitate towards careers where there is much talk, action and contact with others. With introversion people tend to give weight to facts and ideas which explain and underlie what goes on in the world. They tend to gravitate towards careers where ideas need to understood and organised.

\section{Sensing/Intuition}

When using sensing, our minds are concerned with using the five senses to perceive the immediate situation; what is real and tangible, the facts of the case. When we use intuition are minds are concerned with perceiving possibilities; what we can imagine, the abstractions, theories or symbols suggested by facts. In career choices 
sensing types tend to be attracted to work where the products can be seen and measured; intuitive types are more attracted to work which requires the big picture, a future orientation, such as strategic planning.

\section{Thinking/Feeling}

These are the basic mental processes of decision-making. Thinking involves weighing up decisions objectively, with logical analysis; Thinking type people are more drawn towards careers which require logical analysis such as science, engineering and finance. Feeling involves weighing up decisions in terms of values and what we care about. Feeling types are drawn to careers where communicating, teaching and helping are valuable tools.

\section{Judging/Perceiving}

These components determine whether we use a judging mental process (T/F) or a perceiving mental process $(\mathrm{S} / \mathrm{N})$ when we are in extraverted attitude. Judging types prefer to collect just enough data to make a decision. They are organised, decisive and like to plan ahead. Perceiving types prefer to keep their options open for new developments, deferring decisions in case something new and interesting turns up.

The combination of these eight components gives rise to 16 Personality Types which are specifically arranged in the following table according to temperament and attitudes. A very short description of each type is noted. For full descriptions refer to Briggs Myers et al:

\begin{tabular}{|c|c|c|c|}
\hline $\begin{array}{c}\text { ISTJ } \\
\text { Systematic } \\
\text { practical, sensible, } \\
\text { logical, analytical, } \\
\text { detached }\end{array}$ & $\begin{array}{c}\text { ISFJ } \\
\text { Sympathetic } \\
\text { practical, realistic, } \\
\text { thoughtful of } \\
\text { others, sensitive, } \\
\text { kind }\end{array}$ & $\begin{array}{c}\text { INFJ } \\
\text { Insightful } \\
\text { creative, symbolic, } \\
\text { compassionate, } \\
\text { cooperative }\end{array}$ & $\begin{array}{c}\text { INTJ } \\
\text { Visionary } \\
\text { creative, } \\
\text { conceptual, } \\
\text { rational, concise, } \\
\text { objectively critical }\end{array}$ \\
\hline $\begin{array}{c}\text { ISTP } \\
\text { Pragmatic } \\
\text { detached, } \\
\text { objective, } \\
\text { analytical problem- } \\
\text { solvers }\end{array}$ & $\begin{array}{c}\text { ISFP } \\
\text { Considerate } \\
\text { trusting, realistic, } \\
\text { considerate, kind, } \\
\text { observant, factual }\end{array}$ & $\begin{array}{c}\text { INFP } \\
\text { Idealistic } \\
\text { Sensitive, } \\
\text { concerned, caring, } \\
\text { curious, long-range } \\
\text { vision }\end{array}$ & $\begin{array}{c}\text { INTP } \\
\text { Logical } \\
\text { analytical, } \\
\text { mentally quick, } \\
\text { insightful, } \\
\text { ingenious, ideas }\end{array}$ \\
\hline $\begin{array}{c}\text { ESTP } \\
\text { Action- } \\
\text { orientated } \\
\text { practical, realistic, } \\
\text { straightforward, } \\
\text { assertive, rational }\end{array}$ & $\begin{array}{c}\text { ESFP } \\
\text { Friendly } \\
\text { practical, realistic, } \\
\text { generous, warm, } \\
\text { optimistic, tactful }\end{array}$ & $\begin{array}{c}\text { ENFP } \\
\text { Enthusiastic } \\
\text { curious, } \\
\text { imaginative, } \\
\text { friendly, caring, } \\
\text { spontaneous }\end{array}$ & $\begin{array}{c}\text { ENTP } \\
\text { Innovative } \\
\text { creative, curious, } \\
\text { imaginative, } \\
\text { clever, } \\
\text { questioning }\end{array}$ \\
\hline $\begin{array}{c}\text { ESTJ } \\
\text { Decisive } \\
\text { realistic, clear, } \\
\text { assertive, } \\
\text { systematic, matter- } \\
\text { of-fact }\end{array}$ & $\begin{array}{c}\text { ESFJ } \\
\text { Helpful } \\
\text { warm, } \\
\text { personable, } \\
\text { sympathetic, } \\
\text { down-to-earth }\end{array}$ & $\begin{array}{c}\text { ENFJ } \\
\text { Appreciative } \\
\text { warm, loyal, } \\
\text { compassionate, } \\
\text { variety, } \\
\text { challenges }\end{array}$ & $\begin{array}{c}\text { ENTJ } \\
\text { Enterprising } \\
\text { analytical, logical, } \\
\text { innovative, global } \\
\text { thinkers, } \\
\text { theroisers }\end{array}$ \\
\hline
\end{tabular}


The MBTI materials were obtained exclusively from OPP Ltd

(www.opp.eu.com/Home.aspx) who is the sole trainer and resource supplier for $\mathrm{MBTI}$ in the UK.

\section{Methodology}

The survey was conducted in 2008 following four career development workshops which had been delivered at four UK universities during 2006 and 2007. All participants were contacted via email and ten were chosen at random to take part in the qualitative survey. Their basic profiles are as follows and, as can be seen from the status column, two had since taken up new non-research positions at the time of the survey:

\begin{tabular}{|c|l|l|l|l|}
\hline Candidate & \multicolumn{1}{|c|}{$\begin{array}{c}\text { Status } \\
(\text { PD/PG })\end{array}$} & \multicolumn{1}{|c|}{ Gender } & \multicolumn{1}{|c|}{ MBTI Type } & \multicolumn{1}{|c|}{$\begin{array}{c}\text { End of } \\
\text { contract }\end{array}$} \\
\hline A & PD & Female & $\begin{array}{l}\text { ISTJ } \\
\text { (Systematic) }\end{array}$ & April 2008 \\
\hline B & PG & Female & $\begin{array}{l}\text { ENTP } \\
\text { (Innovative) }\end{array}$ & Oct 2008 \\
\hline C & PD & Male & $\begin{array}{l}\text { ENTP } \\
\text { (Innovative) }\end{array}$ & 2012 \\
\hline D & PD & Female & ESTJ (Decisive) & 2012 \\
\hline E & PD & Female & $\begin{array}{l}\text { ENTP } \\
\text { (Innovative) }\end{array}$ & Dec 2009 \\
\hline F & PD & Female & INTJ (Visionary) & July 2010 \\
\hline F & Post-PD & Female & $\begin{array}{l}\text { ISTP } \\
\text { (Pragmatic) }\end{array}$ & Permanent \\
\hline H & PD & Female & INTP (Logical) & Sept 2010 \\
\hline I & PG & Female & INFP (idealistic) & Oct 2008 \\
\hline J & Post-PD & Male & ESTJ (Decisive) & Permanent \\
\hline
\end{tabular}

The questions used in the survey form (see Appendix 1) were intended to determine whether there is a relationship between the career management style and career choice preference of this cohort group with personality type. In choosing the appropriate methodology for the study, a simple survey form requesting a follow-up interview offering career guidance was determined as the best strategy to yield the optimum response rate from those who had attended the workshops over a year ago. The preliminary work which was conducted prior to initiating the survey was to examine the theoretical basis for career choice and to design the questionnaire to ensure that relevant and useable information would be collected. Once established, the survey questionnaire (with closed and open questions) was developed to address firstly the more factual aspects, i.e. which parts of the research work were most appealing, and what intentions were there for the next career move; and secondly, to address their perception of the concept of 'career' and how the respondents preferred to manage their career and career planning. The questionnaire formed the basis of the initial part of the survey and this was then followed up by an unstructured telephone interview in which some of the statements (especially the answers to the open questions) were pursued more thoroughly. The results of the survey were then examined in relation to the individual's MBTI result to determine any qualitative correlations. 
The survey forms were used as a basis for the follow-up unstructured interview and, although it is difficult to make any generalisations with this small number of subjects some patterns were observed. It should be noted that only $20 \%$ of the follow-up survey included males which was due to the fact that two-thirds of the original workshop participants had been female which meant that proportionately fewer males had responded to the second part of the survey.

\section{Results}

The full results obtained from the MBTI analysis including statistical analysis are reported in Blackford (2010) and show the distribution of personality type amongst these bioscientists. For a summary of each survey respondent see Appendix 2. Regardless of a person's personality type in relation to extraversion vs introversion, most individuals reported that they had discussed their career ideas and options with others, especially their friends and colleagues. However, goal-orientated judging types $(\mathrm{J})$ did tend to take a more rational and pragmatic approach and appeared to be more focussed on the future than the more spontaneous perceiving $(P)$ types (compare PD D with PD E where $D$ is taking a more pragmatic view of her career whilst PD E is leaving her options open for as long as she can). Three individuals reporting ENTP as their preferred personality type (intuitive extraverts) varied in their perception of their career: PG B who was due to complete her PhD at the end of that year had been thinking about going into medicine from an early age but, having not achieved the required grades had opted for Biology and a PhD route. She was now planning to go forward with a loose plan to acquire some clinical experience during this year before entering the course in 2009. On the other hand, PD E, who still had two years left on her contract, was very open-ended about her career plans to the point that she did not know what her mindset would be at that point so was not prepared to make decisions until she had this information to hand. The third (PD C) was very clear about his career plans and was seeking to secure an academic post so that he could put his research ideas into action and be able to manage his own research programme. He had had a very positive experience during his post-doctoral post working in a very flexible team-orientated laboratory which suited his working style. The one connecting factor for all these three was their need and wish for variety - in their work, in their ideas, in their environment.

PD A, whose personality type was ISTJ was very much interested in the technical and operative aspects of her work and was keen to continue in a technical or administrative capacity preferably within the university environment. On the other hand, PD F (INTJ) mentioned ideas and concepts many times in her interview. She was also visionary towards the work of herself and of others and even identified science expressed as art as one of her interests/sidelines to her work.

There are many opportunities nowadays for researchers to engage in commerce and enterprise in a variety of ways (e.g. in-house entrepreneurship programmes, Research Council UK programmes such as YES) and PD D (ESTJ) saw herself as well suited to this kind of career. She said she felt her research work was "generating information for the sake of information" and she would prefer to be working towards an end-product or a tangible goal. She identified patent work or industry as her preferred future career, however her primary concern was to change to a career 
which would be more amenable to finding work when she moves back to Australia with her husband. Post-PD J (also ESTJ) moved out of research directly after completing his PhD and, at the time of the survey, was working as a Biotechnology Technical Support officer. He had cited attending conferences, networking and helping others as his most enjoyable activities when he was in research and said he was stimulated when working with others in a team. He was frustrated that the research environment was too "slow" and not conducive to team work which is why he chose to move into a Biotechnology company where, like PD-D he would also be more engaged with people and tangible products. He had been quite pragmatic and strident about his career management once he was sure he wanted to leave research and had made a plan of action after having thought through and researched possibilities by attending career workshops and courses.

Post-PD $\mathrm{F}$ had also left research and was working in a university Virtual Learning Educational department. She reported a personality type of ISTP which reflects a preference for a flexible, problem-solving work environment. She reported being very happy with her work which involves teaching students and staff about the university virtual learning environment system and trouble-shooting problems as they arise which maps well with that described in Hammer (2000).

It was clear that personality played a major role in the way in which people conducted their career management processing, however social and developmental factors were over-riding and fundamental to their career perceptions and choices. According to their experiences in their current research laboratory they had differing perceptions about their future as a researcher. Most of those who reported their wish to leave research said their decision was based on the following factors:

- Research environment is not stimulating enough as the research group is very small with no interaction with others;

- A feeling of being isolated with little or no feedback or praise from their supervisor for what they are doing;

- The need to publish and competitive pressures are very stressful if their research subject does not lend itself to many publications;

- For the majority of the time results are not forthcoming which means repetitive experiments with no tangible output, thus decreasing motivation.

In addition to these reservations, the other overriding factor influencing the career decisions for three of the women interviewed was their current or likely future work/life balance in bringing up a family. They were looking for a less demanding profession with flexibility and support and also wanted to broaden the scope of their options and flexibility with repsect to their partner's work requirements rather than their own. They were prepared to down-shift in this regard or to identify a career which was not so specialised and restrictive.

\section{Discussion}

The factors which influence career choice and career management behaviour are multitudinous and include: (1) immediate environmental influences such as social background, education, local role models, (2) remote influences such as the media, society, culture, economic and political climate and (3) personal influences such as 
personality, physical and mental capabilities, natural talents and abilities, skills etc. (Gothard, Mignot, Offer and Ruff, 2001). For the purposes of this research the influence of personality, as measured using the Myers-Briggs Type Instrument, on the career management and career preferences of bioscientists was studied. However, it is acknowledged that this is simplistic in its isolation and reflects the earlier psychoanalytic theories, 'Trait and Factor' and 'Self-concept' theories. The person-environment theories of Parsons (1910) and Holland (1966; 1985) whereby personality was directly linked to careers and work environments with no reference to other influences still have their place in career guidance.

As reported by Healy (2000), MBTI bipolar dimensions can be correlated with Holland's six vocational personality types: Realistic, Investigative, Artistic, Social, Enterprising and Conventional:

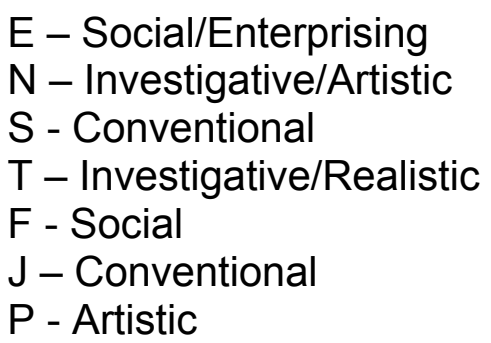

The behaviour of members of this cohort group of subjects for this study is also under the influence of factors which affect their ability to take advantage of the flexibility and transferability of careers in the $21^{\text {st }}$ Century as reported in Gothard et al. (2001). As noted by Baker and Aldrich (1996) "Marriage and the presence of children may have a substantial impact on how a person is affected by the results of employer flexibility". Linked to this is the concept of the development of an identityenhancing career which, according to Baker and Aldrich (1996), can be threatened by the inability to get or keep a job (in particular women who derail their careers to follow their husbands) or by the inability to escape from a self-chosen rut (in this case the post-doc short-contract rut). Much work is being undertaken worldwide in order to address the work-life balance problems faced by women in science much of which is cited as a lack of role models at the senior management level and a work culture which makes it difficult for women to establish themselves as researchers (e.g. seminars held after work rather than during the working day) as reported by Peters, Lane, Rees and Samuels (2002).

Individual behaviour as described by the $16 \mathrm{MBTI}$ personality types can be related to a number of career learning theories. For example, in the final section of his book entitled "Me plc", Hawkins (1999) focuses on aspects of self-reliance and provides a personal audit for readers to assess themselves in terms of their current career management status. A person's behaviour could be affected in this regard by their personality, e.g. J-types tend to be more goal-orientated and plan ahead than Ptypes; Sensing types will prefer to gather lots of factual information as mapped out in the audit whereas Intuitive types may have more conceptual ideas about their career.

The way in which individuals manage aspects of their career will vary according to their personality type. For example, their sensing of career may be realistic and in 
the 'here and now' for $S$ types whereas for intuitive $(N)$ types they may have more of an impression of career rather than drawing on factual information. Introverts may sense in their internal world whilst extraverts are more likely to carry out this stage in the external environment by talking and discussing with others. Thinking types may take a more objective perspective as opposed to feeling types who might rely more on their emotions and take account of how their decisions may affect others. Finally, judging types may make their decisions more quickly than perceiving types before they have considered all possibilities. Conversely perceiving types may procrastinate too much and miss out on opportunities.

McCash (2006) compares Law's DOTS Model with the early theories of the $20^{\text {th }}$ century, e.g. the person-environment fit theory (Parsons, 1910) arguing that career learning and intervention practices have not fundamentally moved on and that the concept of students acting as career researchers is a more preferable practice. His argument stems from the fact that different people view the world and their careers differently and so a structured procedure comprising 'Self-awareness, Decisionmaking, Opportunity awareness and Transition' (i.e. the DOTS Model as proposed by Law and Watts, 1977) does not work for all people, e.g. providing someone with lots of information about careers does not necessarily mean they will then be able to make a decision more easily. This thinking very much reflects that of this study in which differing personality types viewed their careers quite differently. For example, someone whose type consists of $\mathrm{SJ}$ is likely to be more realistic and conventional according to Holland and make use of information in a more functional way than NP types who may be more conceptual and less structured in the way they process the same information.

In conclusion, the results presented here provide a qualitative 'snapshot' of the way in which bioscience postgraduates and postdoctoral researchers view and value their current roles as well as their regard for future careers. Researcher development managers, skills coordinators as well as careers advisers who work with postgraduates and postdoctoral staff may take account of the fact that their clients will differ in the way they approach their personal development, their participation in career development activities and their career aspirations according to their personality as well as other personal and external influences.

\section{Acknowledgements}

This study was conducted as part of a research thesis towards the postgraduate diploma in careers information, education and guidance at the University of Reading. The author would like to thank the Society for Experimental Biology for its financial support towards this qualification as part of the author's continuing professional development.

\section{References}

Baker, T. and Aldrich, H.E. 1996. Promethus Stretches: Building identity and cumulative knowledge in multiemployer careers. In: M.B. Arthur and D.M. Rousseau (eds) The Boundaryless Career. Oxford: Oxford University Press. 
Barshes, N.R., Vavra, A.K., Miller, A., Brunicardi, F.C., Goss, J.A. and Sweeney, J.F. 2004. General Surgery as a Career: A Contemporary Review of Factors Central to Medical Student Specialty Choice. Journal of American College Surgeons. 199 (5), pp792 - 799 .

Blackford, S. (2010). Personality profile of bioscience doctoral research students and postdoctoral researchers. Journal of Psychological Type (in press).

Bradley, D. (2009). http://www.sciencebase.com/contract_research_assistant.html

Briggs Myers, I., McCaulley, M.H., Quenk N.L. and Hammer, A.L. (2003). MBTI manual. A guide to the development and use of Myers-Briggs Type Indicator. $3^{\text {rd }}$. Ed. California: CPP. Inc.

Capretz, L.F. (2008). Psychological types of Brazilian software engineering students. Journal of Psychological Type, 5, 37 - 42.

Gothard, B., Mignot, P., Offer, M and Ruff, M. (eds.). 2001. Careers Guidance in Context. London: SAGE Publications.

Hammer, A.L. (2000). Introduction to type and careers. California: CPP.

Hawkins, P. 1999. The Art of Building Windmills. Career tactics for the $21^{\text {st }}$ century. Liverpool: GIEU.

Healy, C.C. 2000. Interpreting the Myers-Briggs Type Indicator to help clients in understanding their Strong Interest Inventory. Journal of Career Development. 26 (4), pp $295-308$.

Holland, J.L. 1966. The Psychology of Vocational Choice. A Theory of Personality Types and Model Environments. Massachusetts: Ginn and Company.

Holland, J.L.1985. Making Vocational Choices: a theory of vocational personalities and work environments. $2^{\text {nd }}$ Ed. Englewood Cliffs, NJ: Prentice-Hall

Johnson, H.M. and Singh, A. (1998). The personality of civil engineers. Journal of Management Engineering, July/August, 45 - 56.

Jung, C.G. 1923. Psychological Types. New York: Harcourt, Brace

Law, B. 1999. Career-learning space: new-DOTS thinking for career education. British Journal of Guidance and Counselling. 27 (1), pp 35 - 54.

Law, B and Watts, A.G. 1977. Schools, Careers and Community. London: Church Information Office.

National Carer Development Week. http://www.ncdw.com.au/index.php/definition--career-management-skills.html 
McCaulley, M.H. and Martin, C.R. 1995. Career assessment and the Myers-Briggs Type Indicator. Journal of Career Assessment, 3(2), 219 - 239.

McCash, P. 2006. We're all career researchers now: breaking open career education and DOTS. British Journal of Guidance and Counselling. 34 (4), pp $429-449$.

Parsons, F. 1910. Choosing a Vocation. London; Gay Hancock.

Peters, J., Lane, N., Rees, T. and Samuels, G. 2002. SET FAIR. A report on women in science, engineering and technology from The Baroness Greenfield CBE to the Secretary of State for Trade and Industry. http://image.guardian.co.uk/sysfiles/Education/documents/2002/11/28/4408-DTI-Greenfield.pdf 
APPENDIX 1

CAREERS SURVEY

1. Are you a PhD student $\square$, are you a postdoc $\square$ ? Other - please specify in the space below:

When does your current contract end?

2. Have you decided what you want to do for your next career move?

3. If yes, what is it?

4. Please mark the $\mathbf{5}$ ( 1 highest, 5 lowest) most enjoyable activities associated with your work in order of preference. Add in any additional activities not included in this list that you would place in the top 5.

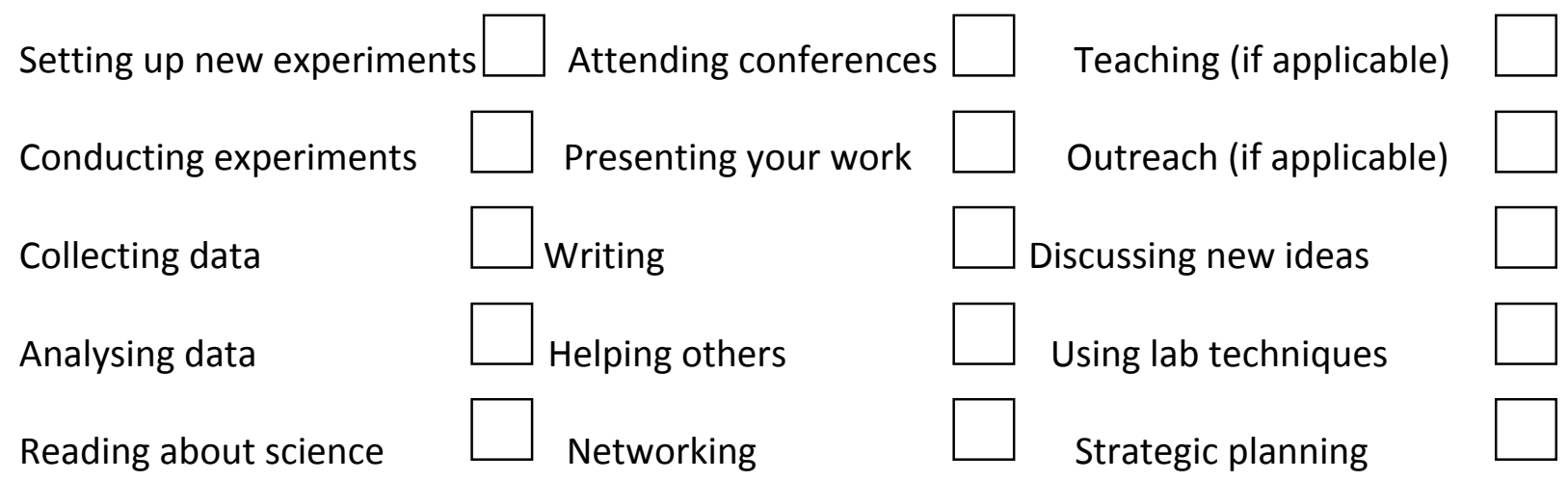

5. Is there anything you especially dislike about your research work?

6. Have you done any of the following towards your next career move?

Talked to colleagues/friends $\square$ Investigated information (e.g. journals, magazines, internet)

Reviewed job vacancies

$\square$ Thought things through and reflected on your own

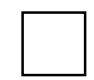

Made a plan of action

Investigated options on an ad hoc irregular basis

Contacted any employers?

Had lots of ideas but not followed them through

Contemplated possibilities

Considered jobs which are related to your skills

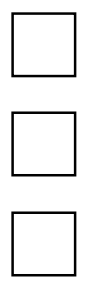


7. Are any of the following occupations attractive to you? If so, please briefly state why.

Scientific research

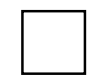

Scientific publishing/writing

Teaching (university/school)

Patent/technology transfer

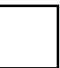

Personnel Development

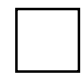

Management role

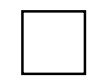

Administrative role

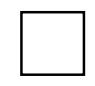

Policy/influential work

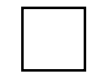

Medicine

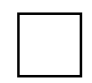

Other, science-related

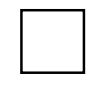

Other, non-science

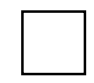

Please note any occupations you are currently considering or think may be of interest to you or provide any other information which you think may be relevant: 
Many thanks for your cooperation. Please return this form indicating a convenient time to have a short follow-up phone call relating to your career plans. If there is anything specific you would like to discuss I will be happy to offer you guidance if appropriate. 


\section{APPENDIX 2}

\section{Careers Survey Results - INTERVIEWS}

\section{A) Post-doc (ISTJ) Transition = April 2008}

The overriding factor in Post-doc A's next career move is flexibility as she is primarily concerned that her work fits in with her family circumstances. She would get the most job satisfaction from staying in science, possibly as a technician, which would mean she could still use her technical skills (which are her most favoured tasks in her current research work) with less pressure and responsibility. She has assessed her own skills and tried to tie them in with those required in other jobs and focussed on technical and administrative work as suited to her. She is considering jobs in technical and administrative work, the latter because it would offer flexibility and make use of her good organisational skills. They both offer a structured and reliable work environment, although she is frustrated from the lack of feedback in her current job. She is currently receiving job information from within the university and from the local council.

\section{B) PhD student (ENTP) Transition = October 2008}

Student B is energised by variety and new challenges. Although she marked conferences, networking and presenting her work as her most favoured tasks in her current research, she is not averse to conducting experiments or analysing data - it's change and variety she needs. She is looking for a people-orientated job with meaning and has some humanitarian aspects to it. She wants to travel (changing environment) with her work and use her knowledge to a good cause. She is deenergised by routine and being isolated with no praise or feedback from others.

Her career plans are based on her needs for variety. Her information related to the career choices is from observing and experiencing others in this and also from her impression of the career. She takes an objective and critical view of career.

\section{C) Post-doc (ENTP) Transition $=2012$}

The research environment in which Post-doc $\mathrm{C}$ works is ideal in terms of his personality. He likes the freedom and flexibility, the variety of his experiments and the large network of colleagues within and outside of the lab. His supervisor provides a supportive and motivational working environment by providing the freedom to his group which allows physical freedom as well as mental freedom. Post-doc $\mathrm{C}$ clearly wants to be able to put his own ideas into action and direct his own research and to re-create this productive research environment for himself. He wants to reach a position where he can plan strategically and make high-level decisions sooner than he would be able to industry (which he considers to be too structured and hierarchical for his tastes). He has had an excellent mentor/role model in his boss who is very 'laid back' allowing him to travel to conferences, present his work and express his ideas. 
Post-doc $C$ ticked the policy box for possible future careers as well as research - this is more related to seeing himself on boards/panels of influence in the future - e.g. medical advisory boards, consultancy. In this respect he is visionary and forwardthinking which relates to the ideas/intuitive aspect of his personality.

\section{D) Post-doc (ESTJ) Transition $=2012$}

In considering her career plans Post-doc $D$ is taking into consideration that she will be moving back to Australia sometime between now and the end of her current contract. Her priority is to open up her options to maximise her employment prospects there. In her current postdoc position she is finding the pressure to publish stressful as her work does not lend itself to lots of publications. Post-doc D says she feels she's not really achieving anything and would prefer to be working towards making a product rather than publications which she feels are written for the sake of writing rather than for any tangible benefit. When she reads academic papers she feels that experiments are done for the sake of the published paper and it comes across as a bit false. She works hard but does not have much to show for it. She gets results but there's no actual end-product. She would like a better measure of her productivity - a more tangible goal.

Post-doc D would much prefer to work in a more structured team-orientated environment such as in industry even if it meant that you had to drop a project and start a new one - so long as your work was meaningful and producing something. She is considering careers related to business - something that is challenging and preferably uses her science. She is considering regulatory affairs-type work where she is writing and acting on behalf of consumers in a more broad and purposeful way. Ultimately she is energised by practical work which has an end-point or product.

\section{E) Post-doc (ENTP) Transition $=$ December 2009}

Post-doc $E$ is undecided about her future and is keeping her options open at the moment. She is currently concentrating on getting results in order to publish since she will need publications if she is to consider academia as a serious career option. She's not concerned however if her future career lies outside her specialist area she says she doesn't know what mind-set she will have in the future so she's openminded about it and doesn't want to plan ahead. At the moment she is currently totally undecided.

Post-doc $\mathrm{E}$ has marked most of her research tasks as enjoyable showing that she enjoys variety and says that whichever task is interesting depends on her mood. She likes to be very flexible and do lots of different things in her daily work - this can mean working till 10.30pm one day and only a few hours the next. She recognises that she may need more stability in the future when work/life balance becomes more important to her but at the moment it's not an issue. Quote: "I don't know where my life will be. Who knows what may come up? My perspectives could change in the next year or so, so what's the point thinking about future careers now?" Post-doc E's 
career possibilities are not based on any solid information and are really impressions - and they changed even during the interview.

\section{F) Post-doc (INTJ) \\ Transition = July 2010}

Post-doc $F$ has been a post-doc for 8 years and is basically running the research lab within a large research programme and has a lot of responsibility. She has built up a lot of experience supervises students, attends meetings and acts as a mentor to those in the lab as well as having her own research project. She encourages members of her group to think independently and to give them the big picture so they have a vision of how their work fits into the grand scheme of things. She sees the value of new ideas/information/concepts.

Post-doc $F$ is applying for fellowships but is aware of the tough competition. Ideally she does not want to move away. She spoke about her interest in the presentation of science through art and presenting science in a different way through posters which are stimulating to people.

\section{G) Learning Resource Manager (ISTP) Permanent job}

G moved out of research while she was doing her first post-doc as she didn't feel it was right for her. She enjoyed experiments, helping others and teaching so when this job came up she thought she would apply as she had suitable skills and experience. She had been thinking of changing into some other kind of work but her application was done spontaneously on the spur of the moment having seen an advert on the university website and after a short phone call with her mother who agreed it was suited to her.

As a researcher $\mathrm{G}$ didn't enjoy the pressure to produce publications and the fact that she never received feedback or thanks for what she was doing. She also felt that she did a lot of work which, when it produced no results, felt like she had not produced anything. She had always been interested in computers and coupled with her teaching experience during her research career and a formal teaching qualification she was well placed to move into this new career. She enjoys the fact that she's been able to remain in the university but in a more sociable and supportive work environment. She enjoys troubleshooting and helping out staff and students as well as teaching them in formal groups. She gets instant feedback and thanks for what she does and is very happy with her career move.

\section{H) Post-doc (INTP) \\ Transition $=$ Sept 2010}

Post-doc $\mathrm{H}$ is doing her $2^{\text {nd }}$ postdoc and would like to stay in research but is disillusioned with the research culture and environment which she feels has become too politicised. She has broad interests and would like to express them by being in charge of her own research. She is looking for a permanent position/fellowship although she is reluctant to teach which could make a permanent position more difficult. Post-doc $F$ is energised when she goes to conferences and hears about 
others' work and has the opportunity to discuss her ideas. She refers to herself as a 'born and raised academic' and her aim is to pursue an academic career but would consider other options such as policy work in order to influence the funding culture which she disagrees with. Alternatively she would consider doing something completely different and creative.

\section{I) PhD student (INFJ) Transition = October 2008}

PhD student l's favourite research activity is setting up new experiments, what she doesn't like is doing the experiments. She could see herself collating and analysing other people's data for them. She likes working with issues which concern the working environment such as excellence in teaching and pedagogy generally. She knows someone in her department who does this kind of work but has not approached her to talk about her ideas as yet. She could imagine herself in this job.

PhD student l's two main concerns about her next career move are: (1) doing something different - research is well known to her - she knows what's expected of her and (2) her personal circumstances - she is not sure where she will be in the next year as she is waiting to see where her partner goes before she makes any decisions regarding her next career move.

\section{J) Biotechnology Technical Support Officer (ESTJ)}

Post-PD J made his decision to leave academia approximately half-way through his $\mathrm{PhD}$. He enjoyed looking at the results he generated from his research but described the working environment as too slow and embittered for his taste. He had intended to forge a career as an academic when he first started his PhD but realised that he liked research less and less and so attended as many career workshops and courses he could to help him decide what to do. He concluded that the courses gave him some insights but he still didn't have any concrete ideas about what he wanted to do except he would like to work in business where he could work as a team with clear goals.

His first job after his PhD was as a market analyst which allowed him to make use of his numerical and intellectual skills but he was interacting with clients and didn't feel so isolated as when working in the lab. Nine months into the job he was contacted by an agency and applied for his current post. He says the job suits him very well as he is working in a team and trouble-shooting scientists' problems, who ring up for help with the company's products. He works in an open-plan office with plenty of interaction and support from others and he has the opportunity to input his ideas into the internal processes and running of the systems. He can see that there is scope for development in the post as there is a career structure in place, as opposed to academia where it is just the supervisor as leader and everyone else working for them with no obvious promotional prospects. 